Vol. 01, No. 1, Mei, 2021

http://journal.um-surabaya.ac.id/index.php/sustainable/index

\title{
ANALISIS PENGENDALIAN INTERNAL SISTEM PENGGAJIAN DAN PENGUPAHAN PADA CV. PROFIL 88 SURABAYA
}

\author{
Della Alamanda \\ Universitas Muhammadiyah Surabaya \\ dellaalamanda98@gmail.com
}

\begin{abstract}
Aspects of globalization about the current economic and business developments are very extensive. Company investment is not a small amount for recruitment costs and employee development costs. In this case, the salary costs are important points especially for companies. This research focuses on internal control of the payroll and wage system on CV. Profile 88 Surabaya. The purpose of this study was to build a supporting system that is useful for analyzing the procedure carried out on payroll and wages whether it has been in accordance with the principle of accounting or not. This study used descriptive qualitative, namely describing a problem occured when the study was conducted. The data source used was primary data with the data collection procedures carried out by documentation, observation and interviews. Based on the results of the analysis in this study, the conclusion is that the control system for payroll and wages on CV. Profile 88 Surabaya was not good enough because there was double functions. The element of internal control in the organizational structure is not well; the authorization system was carried out without authorized approval, healthy practices were carried out according to the calculation of salaries and wages and human resources were less because of the reduction of employees. Some things that are not in accordance with the application of payroll and wage accounting systems especially the recording of work time, making salary lists and paying the salary.
\end{abstract}

Keywords: Learning Interest; Internal Control System, Payroll and Wage

\begin{abstract}
ABSTRAK
Aspek globalisasi secara luas tentang perkembangan ekonomi dan bisnis yang terjadi saat ini. Investasi perusahaan yang tidak sedikit untuk biaya recruitment dan biaya pengembangan karyawan. Dalam hal tersebut biaya gaji menjadi poin penting terutama bagi perusahaan. Penelitian ini berfokus pada pengendalian internal sistem penggajian dan pengupahan pada CV. Profil 88 Surabaya. Tujuan penelitian ini untuk membangaun sebuah sistem pendukung yang berguna untuk menganalisis prosedur yang akan dilakukan atas penggajian dan pengupahan apakah sudah berjalan sesuai dengan prinsip akuntansi atau tidak. Penelitian ini menggunakan kualitatif deskriptif yaitu mendeskripsikan suatu masalah yang ada pada peristiwa yang terjadi saat penelitian dilakukan. Sumber data yang digunakan adalah data primer, prosedur pengumpulan data dilakukan dengan dokumentasi, observasi dan interview. Berdasarkan hasil analisis pada penelitian ini sistem pengendalian untuk penggajian dan pengupahan tidak cukup baik dikarenakan ada perangkapan fungsi. Unsur pengendalian internal pada struktur organisasi tidak terstruktur dengan baik, sistem otorisasi yang dilakukan tanpa persetujuan yang berwenang, praktik yang sehat dijalankan sesuai pada saat perhitungan gaji dan upah dan sumber daya manusia tergolong kurang karena adanya pengurangan pegawai. Beberapa hal yang tidak sesuai dengan penerapan sistem akuntansi penggajian dan pengupahan mengenai pencatatan waktu kerja, pembuatan daftar gaji serta pembayaran gaji.
\end{abstract}




\section{Jurnal Sustainable}

Vol. 01, No. 1, Mei, 2021

http://journal.um-surabaya.ac.id/index.php/sustainable/index

Kata Kunci: Sistem pengendalian internal, Penggajian dan Pengupahan

Submitted: Maret 2021

Revised: April 2021

Accepted: Mei 2021

Correspondence to : dellaalamanda98@gmail.com

\section{PENDAHULUAN}

Dalam perkembangan ekonomi dan bisnis yang terjadi saat ini, perusahaan dituntut untuk meningkatkan efisiensi dan efektifitas dalam pengelolahan sumber dayanya. Suatu perusahaan mempunyai beberapa permasalahan sulit yaitu bagaimana cara perusahaan untuk memelihara para tenaga kerja karena tenaga kerja adalah investasi perusahaan yang tidak sedikit untuk biaya rekrutmen dan biaya pengembangan karyawan. Dalam hal tersebut biaya gaji menjadi poin penting terutama bagi perusahaan yang padat karya. Hal itu tentunya mendapatkan perhatian khusus supaya terhindar dari masalah pemborosan biaya dan penyimpangan dalam proses pembayaran gaji misalnya pada karyawan yang tidak terdata atau karyawan fiktif.

Pemberian gaji dan upah pada suatu perusahaan dapat menjadi manajemen sistem pengendalian yang baik. Pemasalahan-pemasalahan perusahaan, yang dapat menjadi masalah tersebut akan semakin kompleks dengan bertambahnya aktıvitas dalam perusahaan. Untuk mengatasi masalah yang dialaminya, perusahaan khususnya bagian manajemennya harus mengambil keputusan dengan cepat, tepat dan akurat.

Masalah penggajian dan pengupahan tentu sangat penting karena penjelasan atas klasifikasi atau pengalokasian biaya tenaga kerja yang tidak tepat akan mempengaruhi perhitungan laba bersih suatu perusahaan. Penanganan atas gaji dan upah karyawan yang kurang baik atau teliti dapat menjadi hambatan yang menyebabkan keresahan pada tenaga kerja yang akhirnya mempengaruhi kelancaran operasi perusahaan. Dalam hal tersebut maka perusahaan dituntut untuk membuat suatu kebijakan atas sistem penggajian dan pengupahan yang baik dan benar. Hal tersebut adalah bagian penting dari hubungan kerja.

Sistem penggajian dan pengupahan merupakan bagian dari sistem akuntansi internal perusahaan yang akan memberikan informasi secara akurat dan lengkap melalui prosedur dan sistem pencatatan. Informasi ini berkaitan dengan pendapatan yang harus diperoleh setiap 


\section{Jurnal Sustainable}

Vol. 01, No. 1, Mei, 2021

http://journal.um-surabaya.ac.id/index.php/sustainable/index

karyawan salah satunya gajidan upah. Untuk berhati-hati dalam menghadapi kecurangan atau kemungkinanpenipuan, sehingga perlu adanya sistem penggajian dan pengupahan.

\section{TINJAUAN TEORITIS DAN HIPOTESIS}

\section{Sistem Penggajian, Struktur Dan Prosedur Administrasi Penggajian}

Sistem penggajian merupakan proses yang menentukan tingkat penggajian staf, memonitor, mengembangkannya, dan mengendalikannya. Inflasi terus-menerus dan berbagai usaha pemerintah untuk menekannya melalui serangkaian kebijakan pengendalian penggajian, telah menyebabkan adanya ketegangan dalam prosedur pelaksanaan penggajian. Akibatnya yang nyata antara lain adalah pengikisan perbedaan, penyimpangan dalam penggajian, dan struktur penggajian yang sudah tidak memenuhi syarat lagi. Hal ini menimbulkan masalah dalam menarik, memberikan motivasi, dan mempertahankan staf, karena manajemen tidak mungkin lagi mengendalikan secara menyeluruh praktek pemberian gaji (Michael dan Helen, 1983: 1).

Kegiatan penggajian meliputi empat fungsi:

1. Pengangkatan pegawai

2. Pencatatan waktu kerja

3. Pembuatan daftar gaji

4. Pembayaran gaji

Catatan akuntansi dalam sistem akuntansi penggajian dan pengupahan dan dokumen yang digunakan yaitu :

1. Daftar Hadir Karyawan

2. Kartu Jam Hadir

3. Kartu Jam Kerja

4. Daftar Gaji Dan Upah

5. Rekap Daftar Gaji Dan Upah

6. Surat Pernyataan Gaji Dan Upah

7. Amplop Gaji Dan Upah

8. Bukti Kas Keluar 


\section{Jurnal Sustainable}

Vol. 01, No. 1, Mei, 2021

http://journal.um-surabaya.ac.id/index.php/sustainable/index

Jaringan prosedur yang membentuk sistem penggajian dan pengupahan

Sistem penggajian dan pengupahan terdiri dari jaringan prosedur berikut ini :

1. Prosedur pencatatan waktu hadir.

2. Prosedur pembuatan daftar gaji dan upah.

3. Prosedur distribusi gaji dan upah.

4. Prosedur pembuatan bukti kas keluar.

5. Prosedur pembayaran gaji dan upah.

Unit yang terkait penggajian dan pengupahan

1. Bagian Kepegawaian.

2. Bagian Pencatat Waktu.

3. Bagian Gaji dan Upah

4. Bagian Utang

5. Bagian Kasa

6. Bagian Kartu Persediaan dan Kartu Biaya.

7. Bagian Jurnal, Buku Besar dan Laporan.

\section{Sistem Pengendalian Internal}

Pengendalian internal ialah seperangkat kebijakan dan prosedur untuk melindungi aset atau kekayaan perusahaan dari segala bentuk tindakan penyalagunaan, menjamin tersedianya informasi akuntansi perusahaan yang akurat, serta memastikan bahwa semua ketentuan (peraturan) hukum / undang undang serta kebijakan manajemen telah dipatuhi atau dijalankan sebagaimana mestinya oleh seluruh karyawan perusahaan, ketentuan yang meliput peraturan di bidang perpajakan, pasar modal, hukum bisnis, undang undang anti korupsi dan sebagainya. Pengendalian internal atas sistem penggajian yang diperlukan untuk menjamin agar pembayaran gaji dapat dilakukan secara akurat dan topat waktu serta catatan tersedianya catatan akuntansi yang memadai atas penggajian.

Struktur organisasi yang secara tegas memisahkan tanggung jawab dan wewenang terhadap tugas masing-masing individu. Sistem otorisasi yaitu wewenang atas prosedur untuk memberikan perlindungan aset perusahaan. Praktik yang sehat dalam melaksanakan setiap tugas pada setiap bagian struktur organisasi. 
Vol. 01, No. 1, Mei, 2021

http://journal.um-surabaya.ac.id/index.php/sustainable/index

\section{Sistem Akuntansi Penggajian dan Pengupahan}

Sistem akuntansi penggajian serta pengupahan adalah sesuatu sistem prosedur serta catatan- catatan yang digunakan buat menetapkan secara cermat serta pas, atas jumlah pendapatan serta upah yang wajib diterima oleh tiap karyawan, serta tercantum jumlah yang wajib dipotong dari pendapatan serta upah itu buat pajak pemasukan dan sisa pendapatan serta upah yang betul- betul dibayarkan kepada karyawan( Mulyadi, 1993: 11).

Suatu kewajiban perusahaan kepada karyawan dalam bentuk upah dan gaji yang belum dibayar, kadang-kadang cukup besar. Lebih-lebih dalam perusahaan yang memiliki tenaga kerja yang banyak jumlahnya, adapun beban gaji seringkali mencerminkan jumlah yang cukup besar bila dibandingkan beban yang lain.

Pada sistem akuntansi penggajian dan pengupahan dapat terjadi kecurangan-kecurangan. Kecurangan disebabkan dengan adanya karyawan fiktif yang didalam data tercantum tetapi setelah dilakukan pengecekan karyawan tersebut tidak ada. Hal itu tentu menjadi tujuan pada sistem penggajian dan pengupahan diantaranya yaitu sebagai berikut:

1. Secara kilat serta pas bisa dikenal berapa besar pendapatan ataupun upah yang wajib dibayarkan kepada tiap karyawan.

2. Menyelenggarakan catatan- catatan yang efesien serta cermat dari seluruh pendapatan serta upah, potongan- potongan pajaknya serta potongan potongan yang lain.

3. Membayar pendapatan serta upah karyawan dengan metode yang memuaskan.

4. Menyusun secara pas serta cermat seluruh laporan pajak pemasukan serta pajak upah yang diperlukan oleh inspeksi pajak.

5. Menetapkan serta memakai seluruh sistem pengecekan intern buat menghindari kesalahan- kesalahan serta kecurangan- kecurangan.

\section{Catatan akuntansi dalam sistem akuntansi penggajian dan pengupahan}

\section{a. Dokumen yang digunakan}

Dokumen yaitu sebagai media untuk mencatat peristiwa yang terjadi dalam organisasi ke dalam buku catatan. Dokumen termasuk penting dalam akuntansi sebab untuk mencatat dan menghitung gaji dan upah menggunakan bukti-bukti yang terdapat pada dokumen. 
Vol. 01, No. 1, Mei, 2021

http://journal.um-surabaya.ac.id/index.php/sustainable/index

1. Dokumen sebagai pendukung perubahan gaji dan upah. Salinan dokumendokumen ini akan dikirim ke bagian gaji dan upah untuk membuat slip gaji san register penggajian.

2. Kartu jam hadir. Catatan dalam hadir karyawan dapat berupa daftar hadir manual, dapat juga daftar hadir elektronik atau menggunkan mesin.

3. Kartu jam kerja. Sebagai kartu pencatatan waktu kerja setiap bagian, tugasnya untuk mengetahui dengan detail apa yang dilakukan setiap pegawai.

4. Daftar gaji dan daftar upah. Yaitu dokumen yang berjumlah gaji dan upah tiap karyawan, dikurangi potongan-potongan berupa PPh pasal 21, utang karyawan, iuran dan lain sebagainya.

5. Rekap daftar gaji dan rekap daftar upah. Dan sebagai bentuk hasil dari absensi yang dinilai maka rekap daftar gaji dilakukan berdasarkan jam hadir.

6. Surat pernyataan gaji dan upah. Admin keuangn membuat surat pernyataan gaji dan upah untuk memberikan informasi gaji yang diterima. Dokumen ini dibuat sebagai catatan bagi tiap karyawan mengenai daftar gaji dan upah.

7. Amplop gaji dan upah. Dan pada halaman muka berisi informasi menganai nama karyawan penerima gaji atau upah, nomor identifikasi karyawan, jumlah gaji bersih, rincian gaji beserta potongan- potongan antara lain telat, pulang cepat dan lain sebagainya.

8. Bukti kas keluar. Dan berdasarkan informasi dalam daftar gaji dan upah yang diterima dari bagian gaji dan upah.

\section{b. Catatan akuntansi yang digunakan}

1. Jurnal Umum.

2. Kartu harga pokok produk.

3. Kartu biaya.

4. Kartu penghasilan karyawan.

\section{Sistem pengendalian intern dalam penggajian dan pengupahan}

Struktur organisasi yang memisahkan tanggungjawab fungsional secara tegasAdapun fungsi yang harus dipisahkan yaitu : 


\section{Jurnal Sustainable}

Vol. 01, No. 1, Mei, 2021

http://journal.um-surabaya.ac.id/index.php/sustainable/index

1. Fungsi pembuatan gaji dan upah dan harus terpisah dari fungsi pembayaran gaji dan upah

2. Fungsi pencatatan waktu hadir dan harus terpisah dari fungsi operasi.

a. Unit yang terkait penggajian dan pengupahan

1. Bagian Kepegawaian.

2. Bagian Pencatat Waktu.

3. Bagian Gaji dan Upah.

4. Bagian Utang.

5. Bagian Kasa.

6. Bagian Kartu Persediaan dan Kartu Biaya.

7. Bagian Jurnal, Buku Besar dan Laporan.

\section{b. Distribusi beban gaji dan upah}

Gaji dan upah dialokasikan dengan tujuan menghasilkan kalsifikasi laporan biaya tenaga kerja berdasarkan jenis upah dan gaji, tunjangan makan, tunjangan lembur, tunjangan karyawan, dan kombinasi dengan departemen, kegiatan pesanan produksi atau berbagai jenis. Gaji dan biaya upah biasanya dialokasikan melalui metode berikut:

1. Metode Rekening Berkolom.

2. Metode Summary Strip atau tiket tunggal.

3. Metode Distribusi dengan Komputer. 


\section{Jurnal Sustainable}

Vol. 01, No. 1, Mei, 2021

http://journal.um-surabaya.ac.id/index.php/sustainable/index

\section{Kerangka Konseptual}

Gambar 1. Kerangka Konseptual

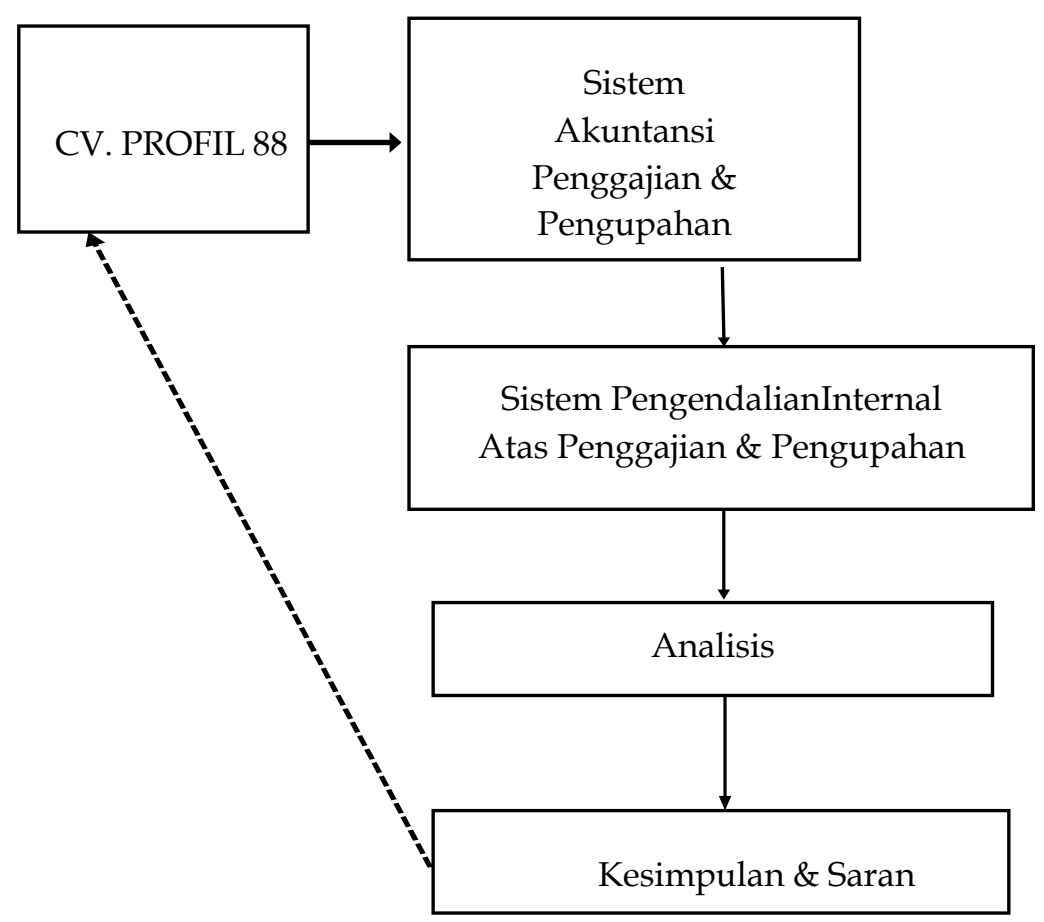

\section{METODE PENELITIAN}

\section{Jenis Penelitian}

Pada penelitian ini yaitu menggunakan metode penelitian deskriptif. Penulis menggunakan pendekatan kualitatif karena penulis ingin memahami fenomena mengenai Analisis Pengendalian Internal Pada Sistem Penggajian dan Pengupahan yang ada di CV. Profil 88 Adapun pengambilan data dilakukan dengan mengadakan observasi secara langsung baik pada kepegawaian maupun kepala departemen bagian penggajian dan pengupahan serta dilengkapi dengan data dokumen dari arsip-arsip yang diperlukan.

\section{Obyek Penelitian}

CV. Profil 88 yaitu perusahaan manufaktur pembuatan Tanki air plastik dan stainless steel yang beralamat di Jl. Lebak Indah Utara 2-4 Surabaya.

\section{Pengumpulan Data}




\section{Jurnal Sustainable}

Vol. 01, No. 1, Mei, 2021

http://journal.um-surabaya.ac.id/index.php/sustainable/index

a. Dokumentasi

Dokumen yang digunakan yaitu laporan absensi (elektronik maupun manual), laporan hasil produksi tangki air setiap harinya dalam periode yang digunakan pada penelitian, rekap gaji untuk karyawan harian maupun borongan, bukti kas keluar untuk pemberian gaji setiap minggunya, laporan perhitungan fee manajemen untuk para karyawan dari perusahaan outsourcing yaitu mitra yang bekerjasama dengan perusahaan CV. Profil 88.

b. Observasi

Pada tahap observasi, dilakukan penyesuaian jobdesk atau tugas setiap karyawan pada bagian penggajian dan pengupahan. Yaitu dengan cara membandingkan struktur organisasi yang ada pada perusahaan CV.Profil 88 dengan hasil observasi. Hal itu perlu dilakukan, apakah selama ini prosedur sudah dijalankan dengan baik atau terjadi penyalahgunaan tugas setiap karyawan.

c. Interview

Penelitian dilakukan dengan cara melakukan wawancara atau tanya jawab pada bagian yang diperlukan pada penelitian ini. Tanya jawab dilakukan secara langsung pada narasumber bagian penggajian dan pengupahan.

Tabel 1 Konsep Interview

\begin{tabular}{lll}
\hline No & \multicolumn{1}{c}{ Konsep } & Interview \\
\hline 1 & Struktur Organisasi & \\
\hline 2 & Sistem Otorisasi & $\square$ \\
\hline 3 & Praktik Yang Sehat & $\square$ \\
\hline 4 & Prosedur Pencatatan & $\square$ \\
\hline
\end{tabular}

\section{Tahapan Analisis}

Langkah-langkah yang dilakukan dalam menganalisa data pada penelitian ini adalah sebagai berikut :

1. Mengumpukan data dan informasi yang diperlukan dalam penelitian ini yaitu pada CV. Profil 88.
a. Dokumen sumber
: Struktur Organisasi 
Vol. 01, No. 1, Mei, 2021

http://journal.um-surabaya.ac.id/index.php/sustainable/index

b. Dokumen pendukung : Absensi, Slip Gaji, Rekap Gaji, dan Bukti Kas Keluar

2. Melakukan interview kepada pihak yang bersangkutan pada penelitian ini.

3. Mengambil kesimpulan dari interview dengan menghubungkan beberapa teori yang ada.

4. Mempelajari dan mengkaji berupa data dari informasi atas pengendalian internal sistem penggajian dan pengupahan.

5. Memberikan kesimpulan atas uraian penjelasan tentang Analisis Pengendalian Internal Sistem Penggajian dan Pengupahan yang dihasilkan pada penelitian di CV. Profil 88.

\section{HASIL PENELITIAN DAN PEMBAHASAN}

\section{Sistem Pengendalian Internal Penggajian}

Beberapa hal yang diperhatikan padasistem pengendalian internalpenggajian yaitu :

a. Struktur Organisasi pada sistem penggajian tidak terlalu rumit. Adapun beberapa fungsi yang terkait penggajian pada CV. Profil 88 Surabaya sebagai berikut:

1. Direktur Utama

Semua kegiatan penggajian dipantau langsung oleh direktur utama, dari mulai acc berapa nilai hasil produksi hingga perhitungan potongan setiap pegawai.

2. Wakil Direksi

Membantu kinerja direktur utama, perhitungan akhir dalam penggajian ditangani oleh wakil manajer sekaligus merangkap pekerjaan sebagai manajer keuangan.

3. Admin Keuangan

Tugas yang dijalankan yaitu mencetak hasil absensi elektronik dengan sistem yang ada. Dan selanjutnya dimasukkan ke dalam Ms.Excel untuk membuat daftar gaji.

1. Admin pembelian

Bertugas untuk melakukan pembelian untuk proses produksi, bagian ini mendapat sistem penggajian untuk perhitungan gaji direkap sama mingguan hanya sebagai ditetapkan sebagai pegawai tetap dengan tunjangan. 
Vol. 01, No. 1, Mei, 2021

http://journal.um-surabaya.ac.id/index.php/sustainable/index

\section{Admin Penjualan}

Merekap penjualan membuat surat jalan, sekaligus pembukuan penjualan. Sistem pembayaran yang diterima yaitu dilakukan sesuai dengan prosedur penggajian.

\section{Admin Piutang}

Melakukan tugas rekap piutang seluruh customer, menyesuaikan pembayaran sesuai dengan jangka waktu yang diberikan. Sistem gaji yang diterima sesuai dengan admin lainnya.

4. Bagian Penagihan

Tugasnya melakukan penagihan secara langsung, sesuai jadwal setiap customer.

b. Sistem otorisasi yaitu menjalankan wewenang atas prosedur yang ada, untuk sistem penggajian dilakukan dengan otorisasi hanya disampaikan melalui lisan. Dari hasi wawancara yang telah dilakukan, pada CV. Profil 88 Surabaya sudah berjalan sesuai dengan sistem otorisasi yang ada serta disetujui setiap bagian. Dari mulai direktur utama memberikan tugas dibantu dengan wakil direksi, wakil direksi melakukan tugas campuran sebagai manajer keuangan. Rekap penggajian dilakukan oleh admin keuangan sesuai dengan daftar absensi dan gaji yang diterima setiap pegawai. Admin piutang bertugas untuk menagih customer dengan dibantu bagian penagihan, karena setiap minggunya gaji diberikan kepada karyawan atas perputaran tagihan. Hasil penjualan direkap oleh admin penjualan. Daftar gaji yang dibuat oleh admin keuangan yaitu laporan perhitungan gaji pada setiap minggu. Diambil dari rekap daftar gaji yaitu laporan gaji setiap bulan yang diserahkan kepada manajer keuangan. Kemudian amplop gaji sebagai bentuk penyerahan gaji yang dimasukkan ke dalamamplop dengan lembaran rincian perhitungan gaji. Penerima gaji tidak diperbolehkan untuk diwakilkan, jika berhalangan hadir pada saat penerimaan pembayaran gaji maka akan diberikan pada saat masuk kembali.

c. Praktik yang sehat. Serah terima gaji dari admin keuangan kepada wakil direksi yang merangkap sebagai manajer keuangan hanya dengan laporan harian dan absensi. Dokumen pendukung yaitu daftar hadir karyawan yang pencatatan dengan sistem 
Vol. 01, No. 1, Mei, 2021

http://journal.um-surabaya.ac.id/index.php/sustainable/index

elektronik.

d. Karyawan yang mutunya sesuai dengan tanggung jawab atas pekerjaannya, sebagai bagian terpenting pada pengendalian internal perhitungan gaji.

\section{Sistem Pengendalian Internal Pengupahan}

Beberapa hal yang diperhatikan pada sistem pengendalian internalpengupahan yaitu :

a. Struktur Organisasi membentuk kerangka organisasi untuk memisahkanbeberapa tugas atau tanggung jawab kepada masing-masing individu. Adapun beberapa fungsi yang terkait pengupahan yang ada pada CV.Profil 88 Surabaya sebagai berikut:

1. Kepada Produksi

Pencatatan hasil produksi tanki air secara manual di terima oleh kepada produksi dan diperiksa untuk selanjutnya diberikan kepada Admin Keuangan.

2. Kepada Sekuriti

Melaporkan absensi manual dan absensi elektronik yang terjadi di pabrik secara periode yang dibutuhkan. tentunya laporan akan diserahkan di bagian Admin Keuangan.

\section{Produksi}

Pengupahan dilakukan untuk membayar upah hasil produksi, produksi meliputi tentang hasil tanki air, hasil tutup tanki, hasil jahit karung, tukang las dll.

\section{Bagian Kontrol}

Setelah produksi selesai, dilanjutkan oleh bagian kontrol produk untuk mengetahui hasil yang baik dan jika terjadi cacat produk akan diserahkan kembali kepada pegawai yang bertanggungjawab. Tentu saja laporan hasil produksi yaitu BSTP (bukti serah terima produk) dikerjakan sekaligus olehbagian kontrol.

b. Sistem otorisasi menjalankan wewenang atas prosedur yang ada, setiap transaksi yang terjadi tentunya disetujui oleh bagian yang mempunyai wewenang dalam hal tersebut sesuai dengan tugasnya. Dari hasi wawancara yang telah dilakukan, pada CV. Profil 88 Surabaya sudah berjalan sesuai dengan sistem otorisasi yang ada serta disetujui setiap bagian. Absensi dilakukan dengan dua metode yakni manual dan elektronik atau sidik jari. Karena pegawai produksi terbagi menjadi beberapa bagian produksi, pencatatan dipantau oleh kepala produksi. Hasil produksi dilaporkan oleh kepala produksi secara 
Vol. 01, No. 1, Mei, 2021

http://journal.um-surabaya.ac.id/index.php/sustainable/index

tertulis yaitu laporan BSTP (bukti serah terima hasil produksi). Produksi dilakukan pengontrolan produk oleh bagian kontrol, dilihat sesuai dengan SNI atau tidak.

c. Praktik yang sehat pada tugas setiap bagian struktur organisasi dibantu dengan pencatatan manual yakni berdasarkan hasil wawancara manajer keuangan sering menemukan kesalahan laporan pengupahan.

d. Karyawan yang mutunya sesuai dengan tanggung jawab atas pekerjaannya, pada poin ini fokus terpenting yaitu permasalahan Sumber Daya Manusia. Pada bagian ini terkadang ada perangkapan tugas seperti pegawai yang memegang kendali atas produksi tanki tetapi juga merekap pekerjaan pembuat tutup tanki.

\section{Penerapan Sistem Akuntansi Penggajian Dan Pengupahan}

a. Pencatatan waktu kerja

Hal ini dilakukan dengan sistem manual dan elektronik. Pencatatansecara manual dilakukan pada tempat produksi atau pabrik yaitu kepala sekuriti dengan mengisi form lembaran sedangkan secara elektronik yaitu menggunakan mesin sidik jari. Kegiatan tersebut dilakukan di pabrik maupun di kantor tempat pembukuan. Berikut adalah jumlah karyawan beserta waktu kerjanya :

Karyawan perusahaan secara keseluruhan dengan rincian jumlah pegawainya
a) Staf kantor
b) Karyawan borongan
c) Karyawan harian pabrik

Dalam praktiknya perusahaan menerapkan sistem pemberian gaji hanyasatu sistem yaitu mingguan. Semua gaji diberikan pada hari sabtu sore.

b. Pembuatan daftar gaji

Pencatatan daftar gaji yaitu menggunakan beberapa ketentuan yang ada, karena perusahaan CV. Profil 88 Surabaya perusahaan manufaktur.

c. Pembayaran gaji

Untuk proses pembayaran gaji dilakukan yaitu memberikan upah atau gaji kepada tiap karyawan, yang dimasukkan ke dalam amplop sesuai dengan nama dan nomor absen. Didalam ampol berisikan rincian gaji beserta potongan-potongan yang ada. 
Vol. 01, No. 1, Mei, 2021

http://journal.um-surabaya.ac.id/index.php/sustainable/index

Adapun perbedaan penerapan sistem akuntansi penggajian dan pengupahan terletak pada perhitungan gaji dan upah.

\section{Analisis Penerapan Pengendalian Internal Gaji Dan Upah}

a. Penetapan Tanggungjawab

Perusahaan membuat ketentuan tentang tanggungjawab atas pekerjaan setiap karyawan. Pemisahan Tugas Penelitian ini dilakukan pada tahun terjadinya pengurangan pegawai, akibatnya terjadi perangkapan tugas.

b. Prosedur Dokumentasi

Untuk hasil penelitian ini mengenai penerapan prosedur dokumentasi tentang penggajian dan pengupahan sudah dijalankan dengan baik. Laporan hasil produksi untuk menjadi perhitungan tentang penggajian diarsipkan dengan baik, absensi manualmaupun hasil elektronik di print dan di file dengan rapi sesuai owner yang disediakan.

d. Pengawasan Fisik

Pengawasan fisik termasuk dalam perlindungan aset, penyimpanan aset perusahaan yaitu dokumen - dokumen penting tentu saja disimpan dengan baik. Dan ataupun terjadi selisih mengenai pajak biasanya dokumen pendukung ikut disertakan atau dilampirkan.

e. Verifikasi Internal Secara Independen

Hasil dari verifikasi internal secara independen di review ulang yaitu berkaitan dengan data secara periodik atau secara dadakan. Untuk perusahaan CV. Profil 88 audit internal tidak ada, jadi kesalahan perhitungan gaji dilakukan pemeriksaan oleh manajer keuangan secara langsung.

Beberapa hal dianggap kurang sesuai dengan pengendalian internal sistem penggajian dan pengupahan. Dalam hal ini peneliti memiliki bukti - bukti mengenai dokumen terkait yang menjadi sela yang dapat menimbulkan kecurangan. Adapun bukti - bukti mengenai permasalahan tersebut yaitu sebagai berikut:

a. Struktur Organisasi

Pada bagian struktur organisasi saat pengambilan data untuk penelitian ini, ada sedikit perbedaan dengan struktur organisasi tahun lalu. Hal itu dikarenakan adanya 
Vol. 01, No. 1, Mei, 2021

http://journal.um-surabaya.ac.id/index.php/sustainable/index

pengurangan pegawai terutama pada bagian penggajian dan pengupahan. Dimulai dari bagian penetapantanggungjawab setiap individu. Pimpinan CV. Profil 88 menegaskan bahwa setiap pegawai bagian administrasi memiliki tanggungjawab penuh pada semua tugas tak terkecuali pada bagian penggajian, tentu saja pengambilan absensi elektronik yang seharusnya dilakukan oleh satu orang dapat diakses dengan mudah oleh bagian administrasi yang lain. Untuk pembahasan mengenai perhitungan gaji, CV. Profil 88 tidak menetapkan prosedur yang dijalankan sebagaimana mestinya. Admin Keuangan melakukan perhitungan dengan metode yang digunakan sendiri tanpa persetujuan dari Manajer Keuangan. Tentu hal itu berbeda dengan sistem akuntansi yaitu setiap perubahan atas informasi tersebut harus selalu dicatat dan mendapat persetujuan dari bagian yang bersangkutan. Rangkap fungsi tugas yang terjadi pada CV. Profil 88 dapat menjadikesalahpahaman dan ketidakakuratan data, perangkapan tugas yangseharusnya dilakukan oleh beberapa orang pada setiap bagian tetapi dijalankan dengan hanya satu orang saja.

b. Sistem Otorisasi

Sistem otorisasi yang digunakan terkadang tanpa persetujuan atasan lebih dahulu. Ketika mengerjakan perhitungan gaji ada beberapa potongan yang tidak ditetapkan dalam prosedur perusahaan. Seperti hal nya pengambilan absensi yang dapat dilakukan semua bagian administrasi. Hal itu tanpa persetujuan atasan terlebih dahulu, tetapi dirasa hal itu mempermudah akhirnya atasan mempersetujui untuk tetap dilakukan dengan syarat bahwa tetap diarahkan oleh wewenang yang hanya diberikan kepada admin keuangan.

c. Praktik Yang Sehat

Selama menjalankan penelitian ini, untuk proses kegiatan penggajian sudah sesuai dan benar. Hanya terkadang perhitungan gaji borongan terdapat selisih dari laporan hasil produksi.

d. Karyawan Yang Mutunya Sesuai

Dalam hal ini perusahaan menetapkan jobdesk sesuai dengan pengalaman setiap pegawai, adapun perangkapan tugas yang dilakukan oleh satu orang. Sudah menjadi bahan pertimbangan oleh atasan untuk dilakukan sesuai dengan kemampuan 


\section{Jurnal Sustainable}

Vol. 01, No. 1, Mei, 2021

http://journal.um-surabaya.ac.id/index.php/sustainable/index

pegawainya. SDM yang ada pada perusahan memang tergolong kurang.

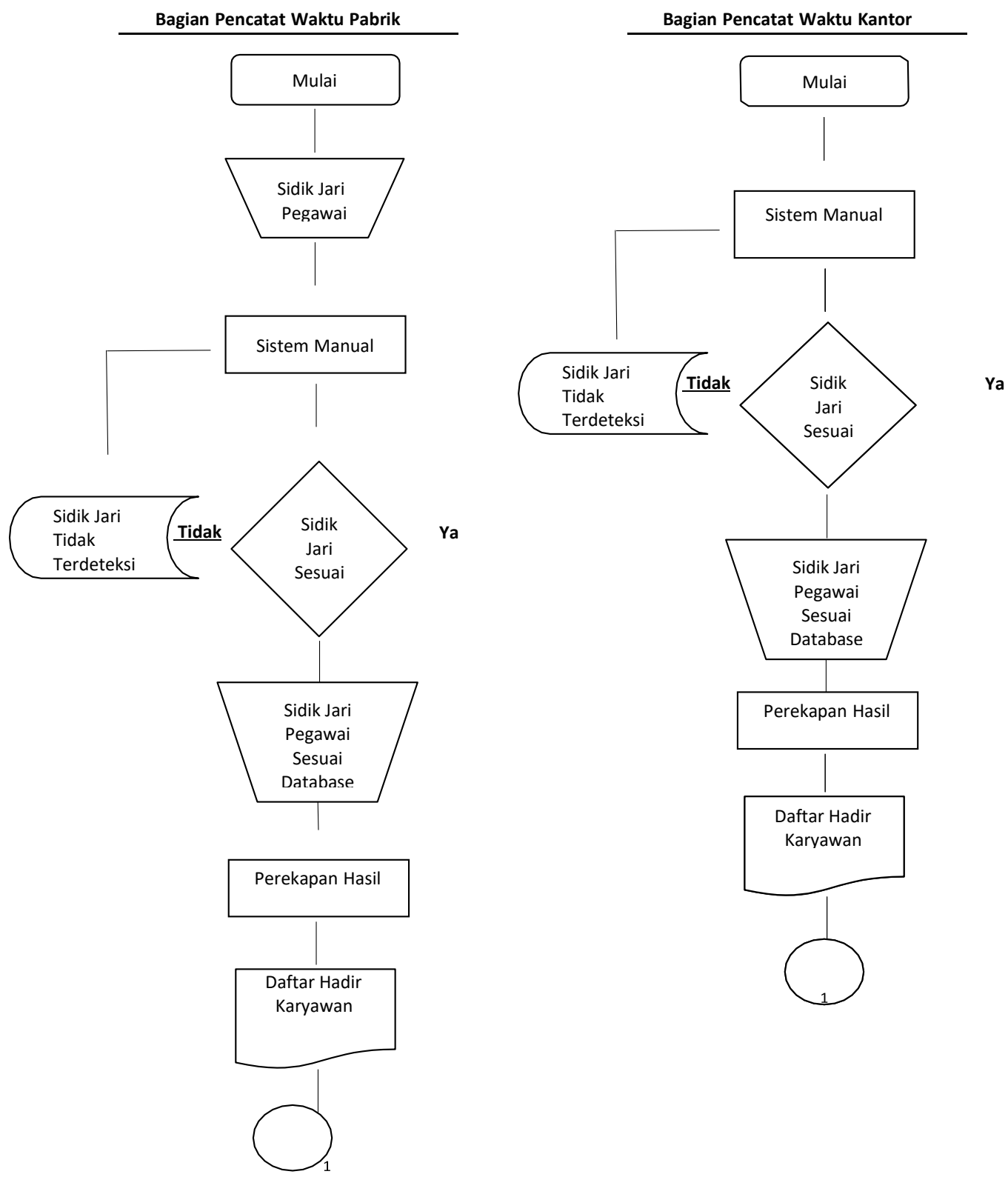

Gambar 2. Bagan Alur Penggajian Dan Pengupahan CV. Profil 88 


\section{Jurnal Sustainable}

Vol. 01, No. 1, Mei, 2021

http://journal.um-surabaya.ac.id/index.php/sustainable/index

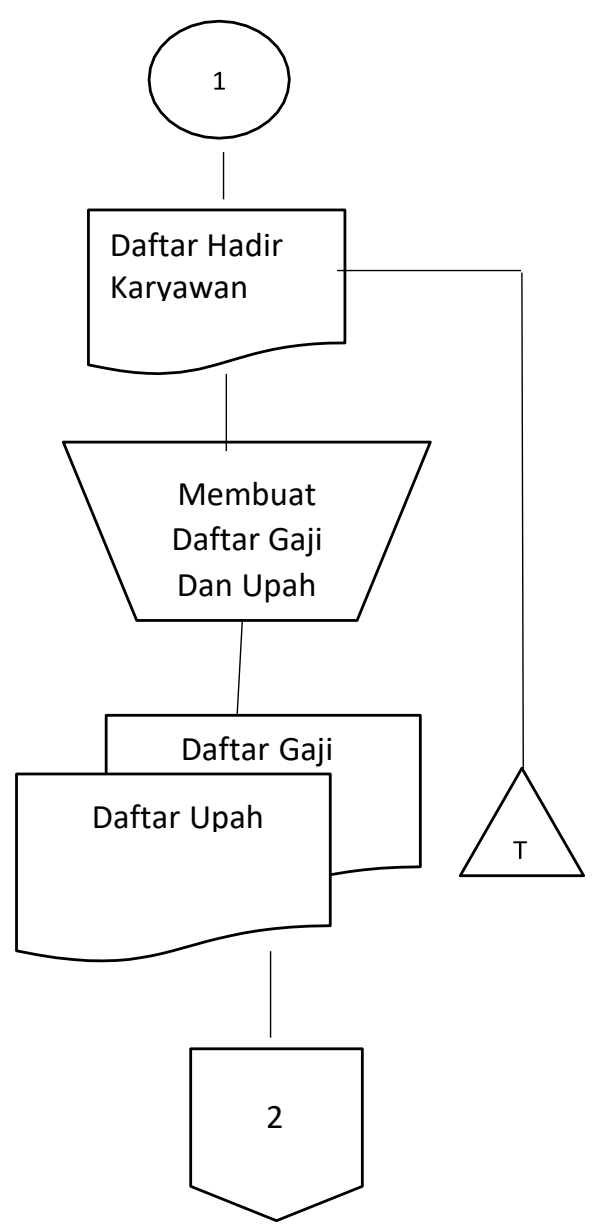

Gambar 3. Bagan Alur Penggajian Dan Pengupahan CV. Profil 88 (Lanjutan) 


\section{Jurnal Sustainable}

Vol. 01, No. 1, Mei, 2021

http://journal.um-surabaya.ac.id/index.php/sustainable/index

\section{Bagian Pembayaran Gaji Dan Upah}
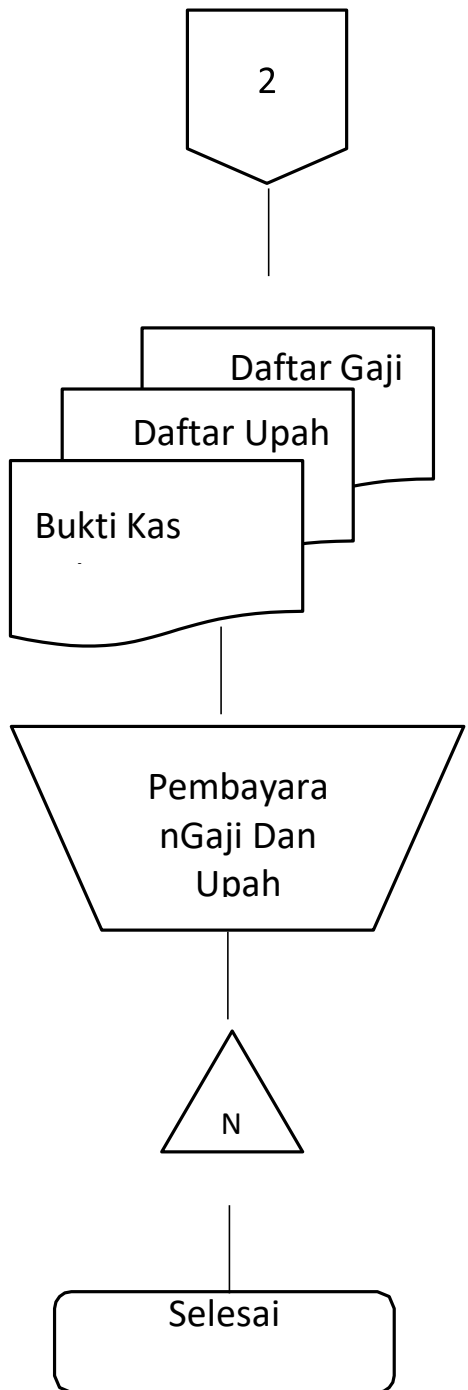

Gambar 4. Bagan Alur Penggajian Dan Pengupahan CV. Profil 88 (Lanjutan) 
Vol. 01, No. 1, Mei, 2021

http://journal.um-surabaya.ac.id/index.php/sustainable/index

Sistem penggajian dan pengupahan padaCV. Profil 88 Surabaya sebagai berikut:

1. Prosedur Pencatatan waktu hadir

Perusahaan CV. Profil 88 Surabaya memiliki dua titik pencatatan waktu hadir. Yang pertama berada di pabrik tempat produksi dan yang kedua di kantor tempat pembukuan, pencatatan dll. Prosedur pencatatan waktu hadir kedua titik tersebut berbeda. Jika di pabrik pencatatan dilakukan dengan dua cara yaitu melalui fingerprint atau melalui sidik jari, kedua pencatatan manual yang dilakukan oleh kepala sekuriti. Sistem penggajian dilaksanakan mingguan atau hari sabtu, jadi dilakukan pengambilan download absensi untuk perhitungan gaji maupun upah. Untuk absensi pabrik dicek apakah kedua pencatatan waktu manual maupun elektronik sudah sesuai atau tidak, jika terjadi selisih waktu Admin Keuangan menanyakan kepada kepala sekuriti.

2. Prosedur pembuatan gaji dan upah

Pembuatan gaji dan upah dilakukan dengan dua prosedur yakni harian dan borongan. Perhitungan gaji harian diberikan kepada pegawai kantor sedangkan untuk borongan diberikan kepada pegawai produksi. Perhitungannya tentu saja berbeda. Untuk perhitungan dilakukan berdasarkan berapa hari kerja dipotong denda terlambat, potongan hutang, potongan BPJS, dll. Laporan yang menjadi acuan perhitungan yaitu BSTP (Bukti Serah Terima Produksi). Bagian admin keuangan menghitung berdasarkan laporan tersebut dan dikalikan hasil produksi yang setiap minggunya.

3. Prosedur pembayaran gaji

Setelah perhitungan dilakukan oleh bagian admin keuangan, laporan tersebut diserahkan kepada manajer keuangan untuk dilakukan pemeriksaan ulang. Setelah semua sudah sesuai dengan hasil absensi dan hasil produksi. Manajer keuangan memberikan sejumlah uang sesuai dengan perhitungan. Kemudian admin keuangan menghitung sesuai gaji yang diterima oleh setiap pegawai dan dimasukkan ke dalam amplop beserta selembar rincian gaji setiap pegawai.

\section{KESIMPULAN}

Ada beberapa hal yang tidak sesuai dengan sistem akuntansi. Yang menjadi acuan penelitian ini yaitu pada unsur pengendalian internalnya. Terjadi perangkapan tugas karena 
Vol. 01, No. 1, Mei, 2021

http://journal.um-surabaya.ac.id/index.php/sustainable/index

minimnya pegawai membuat beberapa pekerjaan pada perusahaan CV. Profil 88 Surabaya dilakukan secara bersamaan. Tidak adanya serah terima ketentuan mengenai sistem penggajian, karena beberapa potongan yang sering menjadi celah kesalahan dalam perhitungan gaji setiap minggu. Ketentuan yang dibuat oleh manajer keuangan hanya disampaikan lisan tidak tertulis, itu menjadi salah satu kelemahan dalam pelaporan gaji. tidak ada pembukuan yang dilakukan oleh admin keuangan. Pelaporan bukti kas keluar juga tidak dilakukan. Rekap gaji hanya ada di komputer saja. Tentunya untuk hasil pencatatan waktu, absensi, maupun perhitungannya cukup sederhana karena sistem yang digunakan juga terbilang manual.

\section{SARAN}

1. Bagian fungsi pencatat waktu dengan pembuat daftar gaji dilakukan dengan karyawan sama, tentu sistem pengendalian internalnya kurang baik bagi perusahaan.

2. Harus menetapkan struktur organisasi, perangkapan tugas dilakukan tidak lain karena struktur organisasi tidak diterapkan. Bagian - bagian yang ada pada sistem gaji dan upah hanya dilakukan dengan satu orang saja

3. Koordinasi antara admin keuangan dan manajer keuangan tidak pernah dilakukan tertulis, komunikasi menjadi bercabang. Pada saat penyerahan perhitungan gaji sering terjadi kesalahan tiap minggunya, terutama pada potongan gaji.

\section{DAFTAR PUSTAKA}

Amstrong, Michael \& Helen Murlis. 1983. Sistem Penggajian, Pedoman Praktis Bagi Organisasi Kecil dan Menengah, eri Manajemen No 84, Jakarta.

Bungin, Burhan. 2008. Penelitian Kualitatif: Komunikasi, Ekonomi, Kebijakan Publik dan Ilmu Sosial Lainnya. Jakarta: Kencana.

Charles T. Horngren dan Walter T.Harrison. 2007. Akutansi Jilid 1, Edisi ke-7. Jakarta: Penerbit Erlangga.

Ending. 2016. Analisis Sistem Pengendalian Internal Atas Sistem Penggajian Karyawan Pelaksana Pada PT. Perkebunan Mitra Ogan (Kebun Batanghari Leko). Jurnal ASCV. 5 (2): 37-49.

Fatihudin, Didin. 2015. Metodologi Penelitian untuk Ilmu Ekonomi Manajemen dan Akuntansi. Sidoarjo: Zifatama Publisher. 


\section{Jurnal Sustainable}

Vol. 01, No. 1, Mei, 2021

http://journal.um-surabaya.ac.id/index.php/sustainable/index

Hardani et al. (2020). Metode Penelitian Kulaitatif dan Kuantitatif. CV. Pustaka Ilmu :Yogyakarta.

Hery. 2014. Akuntansi Dasar 1 dan 2. Jakarta: PT Gramedia Widiasarana Indonesia.

Marshall B. Romney dan Paul John Steinbart. 2014 Sistem Informasi Akuntansi: Accounting Information Systems (Edisi 13), Prentice Hall.

Mulyadi. 1993. Sistem Akuntansi. Yogyakarta: STIE YKPN.

Mulyadi. 2001. Sistem Akuntansi Edisi Tiga. Jakarta: Salemba Empat.

Mulyadi. 2008. Sistem Akuntansi. Jakarta: Salemba Empat.

Mulyadi. 2016. Sistem Akuntansi. Edisi 4. Jakarta. Penerbit: Salemba Empat.

Moekijat. 1989. Pengantar Sistem Informasi Manajemen, edisi 8. Bandung: Remaja Rosdakarya.

Moleong, L.J.1989. Metodologi Penelitian Kualitatif. Bandung: Remaja Rosdakarya.

Susanto, Azhar. 2009. Sistem Informasi Akuntansi. Bandung: Lingga Jaya.

Rizkiyatus Sholiha. 2018. Evaluasi Sistem Dan Prosedur Penggajian Dan Pengupahan Untuk Meningkatkan Pengendalian Internal Perusahaan (Studi Kasus Pada PT. Matabiru Indonesia). Jurnal Sketsa Bisnis. 5 (1): 39-48.

Rosyada, Dede. 2020. PenelitianKualitatif Untuk Ilmu Pendidikan. (Edisi 1. Cetakan ke 1) Jakarta: Prenadamedia Group.

Sandu Siyoto dan M.Ali Sodiq. 2015. Dasar Metodologi Penelitian. Literasi Media Publishing. Yogyakarta: Literasi Media Publishing.

Sugiyono. 2012. Memahami Penelitian Kualitatif. Bandung: Alfabeta.

Sugiyono. 2018. Metode Penelitian Kuantitatif dan Kualitatif dan R\&D.

Yusuf, Haryono. 2011. Dasar - Dasar Akuntansi. (Edisi 7. Cetakan ke-1) Yogyakarta: Sekolah Tinggi Ilmu Ekonomi YKPN.

Zulaika Aquarisma dan Yuli Nurhayati. 2017. Analisis Sistem Pengendalian Intern Penggajian Dan Pengupahan Terhadap Karyawan PT. Bumi Beliti Abadi Kabupaten Musi Rawas. Jurnal Ilmiah Ekonomi Global Masa Kini. 8 (3). 